\title{
Evaluation of the Effects of Various Preparations of Dichlorvos-Treated Beans on the Biochemical and Haematological Parameters of Male Wistar Albino Rats
}

Darlington O. Nwauzobilom, Paulinus C. Nwuke (Corresponding author), Christian E. Odo

Department of Biochemistry, Michael Okpara University of Agriculture, Umudike, Abia State.

Nigeria. E-mail: nwauzobilomdarlington93@gmail.com

Received: Jan. 3, 2020 Accepted: Mar. 15, 2020

doi:10.5296/jbls.v11i1.16696 URL: https://doi.org/10.5296/jbls.v11i1.16696

\begin{abstract}
This study was aimed at evaluating the hepatotoxicity, haematological and antioxidant effects of differently prepared (parboiled and un-parboiled) beans treated with sniper (i.e. a dichlorvos insecticide) and fed to albino Wistar rats. Thirty (30) male albino wistar rats of known body weight were assigned into six (6) groups of 5 rats each. The beans were treated with $0.7 \mathrm{ml}$ (high dose) and $0.3 \mathrm{ml}$ (low dose) of dichlorvos per one $\mathrm{kg}$ of beans. Group 1 and group 2 of un-parboiled beans compounded with standard feed stock, group 3 and group 4 were fed with high dose and low dose of parboiled beans compounded with feed stock, group 5 received beans only while group 6 received standard feed for a period of 30 days. The rats were euthanized, and blood samples were collected after the termination of the study. The increases in the activities of liver enzymes (ALT, AST and ALP) in the rats' sera of different groups showed a hepatocellular damage as a result of dichlorvos toxicity which also significantly $(\mathrm{P}<0.05)$ decreased the activities of the antioxidant enzymes $(\mathrm{GSH}, \mathrm{GPx}, \mathrm{SOD}$, CAT) in the rats of groups fed with un-parboiled beans unlike the groups fed with parboiled beans which were non-significantly decreased. There was significant increase in the malondialdehyde concentration of the rats of the groups fed with un-parboiled beans when compared to group 6 rats. Dose dependent variations were seen in the packed cell volume (PCV), white blood cell (WBC), haemoglobin ( $\mathrm{Hb}$ ) and platelet. However, a reduced concentration of red blood cell count (RBC) for the un-parboiled groups and an increase in the parboiled group were seen, although both were not significant $(\mathrm{P}<0.05)$. Consumption of un-parboiled beans exposes consumers to the risk of dichlorvos contamination and its harmful effects as seen in this study, hence there is need for the parboiling of beans which helps to reduce the dichlorvos residues deposited on beans.
\end{abstract}

Keywords: Hepatotoxicity, Dichlorvos, Vigna unguiculata, and Antioxidant enzymes 


\section{Introduction}

Cowpea (Vigna unguiculata) is a food legume of the family Fabaceae/Papilionaceae (1) which is universally consumed. In Nigeria, it is known by names such as "akidi" in Igbo language, "ewa" in Yoruba language and "wake" in Hausa language. Nigeria, Niger and Brazil are the major cultivators of cowpea (2), (3). In Nigeria, it is grown as a cash crop besides its value as food crop. It is planted and stored majorly in the northern states. During storage, pesticides are added to prevent the attack of different pests but sometimes they are used indiscriminately. This has led to the detection of pesticide residues on beans exported from Nigeria (4), (5). Cowpea provides the body with a high-quality protein constituent of the daily diet among economically depressed communities in developing countries, thereby bridging the gap created by inadequate supply of protein in the body (6), (3), (7).

Pesticides are ubiquitous and global statistics have revealed increasing use of these chemicals for the control of pests (8). Although pesticides play great roles in the management of agricultural enterprise, where they potentiate yields and protect crops against insects at post-harvest and storage which has given modern agriculture a solid foundation because of its unquantifiable benefits one of which include enhancement of shelf life of stored agricultural products (9). It is worthy of note that insects and pests are getting immune to the commercial pesticides due to over usage, hence leading to the development of multiple pesticides with different active ingredients targeted on multiple species (10) as well as diversifying modes of application of pesticides where sometimes they are mixed directly with the agricultural product being preserved. The major pesticides used in Nigeria for cowpea preservation are cypermethrin (11) and organophosphates especially dichlorvos. But sequel to the high importation of pesticides, their prices have become so high making it difficult for local farmers to afford hence, they have resorted to locally formulated dichlorvos-based pesticides called ota-piapia (4) which tends to be more accessible to them.

Dichlorvos (2,2-dichlorovinyldimethylphosphate) was first introduced in 1961 (12). It has a molecular formular $\mathrm{C}_{4} \mathrm{H}_{7} \mathrm{Cl}_{2} \mathrm{O}_{4} \mathrm{P}$ and molecular weight to be 220.98 (Fig 1). It is one of the most commonly used organophosphate pesticides in developing countries (13). The WHO categorized it as Class IB, 'highly hazardous chemical (14).

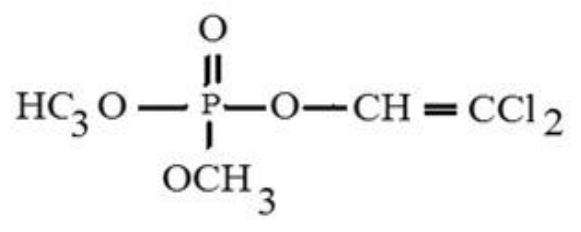

Dichlorvos

Figure 1.1. Molecular formular $\mathrm{C} 4 \mathrm{H} 7 \mathrm{Cl} 2 \mathrm{O} 4 \mathrm{P}$ and molecular weight to be 220.98

Dichlorvos is a highly volatile organophosphate, a pesticide which is used to control domestic pests, in environmental health, as well as preserving stored agricultural produce from storage insects like weevils. Organophosphates function mainly by the inhibition of acetylcholinesterase - an enzyme that breaks down acetylcholine (15), (16), (17). It is mainly metabolized by esterase to dimethyl phosphate and dichloroacetaldehyde in mammals (18), (19). 


\section{Macrothink}

Oxidative stress has been identified as an important molecular mechanism of toxicity of DDVP. It is defined as an imbalance between the production of free radicals and the antioxidant system of the body (20). Enzymatic and non-enzymatic antioxidants scavenge free radicals and reactive oxygen species (ROS) in biological systems (21).

DDVP toxicity should be explored because the residues of DDVP have been detected in food stuffs in several countries including Nigeria(22). Although some studies have been conducted to evaluate the effect of dichlorvos insecticide on blood, the purpose of this study is to determine the effects of un-parboiled and parboiled DDVP-treated beans on the integrity of the liver and kidney.

\section{Materials and Method}

\subsection{Feed Formulation}

\section{A. Beans preparation}

Beans were bought in Ultra-modern market, Ubani, Umuahia, Abia State, Nigeria. Dichlorvos based-pesticide, Sniper, was mixed with $1 \mathrm{~kg}$ beans to achieve $1 \mathrm{ml} / \mathrm{kg}$ and air dried for one (1) week. The contaminated beans were washed and completely cooked without parboiling and a no spices were added.

\section{B. Feed formulation}

Dichlorvos based-pesticide, sniper was mixed with beans with the ratio of $1 \mathrm{ml}: 1 \mathrm{~kg}$ (i.e. dichlorvos: beans) and aired for one (1) week. The contaminated beans were group and prepared (cooked) separately where one group was parboiled and the other was not parboiled. Each group was sundried and ground into flour, mixed with feed at different ratios to determine the different concentrations of dichlorvos in each sample, while another sample which contained beans only was prepared.

\subsection{Chemicals}

Commercial grade dichlorvos (DDVP, 100\% solution containing $100 \mathrm{~g}$ per liter of 2,3-dichlorovinyl dimethylphosphate) marketed as Sniper ${ }^{\circledR}$ was purchased from an agrochemical company in Umuahia, Nigeria. DDVP was reconstituted in soya oil (SO, Grand Cereals and Oil Mills Limited, Jos, Nigeria) to a 5\% stock solution.

\subsection{Experimental Design}

- Group $1=$ High conc ddvp in parboiled beans + feed (ie. $70: 30)+$ water.

- Group 2 = Low conc of ddvp in parboiled beans + feed (ie. $30: 70)+$ water.

- Group 3 = High conc of ddvp in unparboiled beans + feed (ie. $70: 30$ ) + water

- Group 4 = Low conc. of ddvp in unparboiled beans + feed (ie. $30: 70)+$ water

- Group 5 = Beans only (Negative control)

- Group 6 = Feed + water only (Positive control) 
The rats were fed with the samples and closely monitored for four (4) weeks. At the end of the experimental weeks, the rats were anaesthetized with chloroform, sacrificed by cervical dislocation and blood samples collected through cardiac puncture using $2 \mathrm{ml}$ syringes. Blood samples for biochemical assays were collected in plain tubes and allowed to clot before centrifugation and the sera were separated thereafter and used for the assays, while the blood samples for haematological parameters were collected in EDTA-containing sample bottles and used for the tests.

\subsection{Assays of the Activities of Serum Liver Enzymes}

Aspartate aminotransferase (AST) activity was assayed according to the method of Reitman and Frankel (1957) (23). The principle of this method is that oxaloacetate reacts with AST and is decarboxylated spontaneously to pyruvate. The pyruvate is measured by hydrazone formation after pyruvate reacts with 2,4 dinitrophenylhydrazine (DNPH) to give a brown coloured hydrazone which can be measured at $546 \mathrm{~nm}$.

Serum ALT activity was estimated by the method of Reitman and Frankel (1957) (23). This method is based on the production of pyruvate by the transamination activity of alanine amino transferase. Pyruvate reacts with 2, 4-dinitrophenylhydrazone (DNPH) to give a brown coloured hydrazone that is measured colorimetrically at $546 \mathrm{~nm}$.

The activity of alkaline phosphatase (ALP) was assayed using the method of Kochmar and Moss (1976) (24). This is based on the principle that in the presence of magnesium and zinc ions, p-nitrophenol phosphate is hydrolyzed by phosphatase to form phosphate and p-nitrophenol. The p-nitrophenol released is proportional to the alkaline phosphatase (ALP) activity and can be measured photometrically.

\subsection{Assays of the Activities of Serum Antioxidant Enzymes}

Superoxide dismutase activity was assayed by the method of Arthur and Boyne (25) as contained in Randox kit. Catalase activity was assayed with the randox kit according to the method described by Sinha (26). Glutathione peroxidase (GPx) was measured according to the method of Paglia and Valentine (27), while the reduced glutathione level was determined by the method of Exner et al. (2000) (28).

\subsection{Hematological Evaluations}

The total white blood cell count was determined by haemocytometry following the method described by Ochei and Kolhatkar (2008) (29). The method of Ochei and Kolhatkar (2008) (29) was used for the determination of red blood cells, where, the blood specimen was diluted 1:200 with RBC diluting fluid and cells were counted under high power (40X) objective by using a counting chamber. The number of cells was calculated and reported as the number of red cells $/ \mathrm{mm}^{3}$ of whole blood. The packed cell volume was determined using the microhaematocrit centrifuge (Jouan A13 model). The haemoglobin (Hb) concentration was measured spectrophotometrically by cyanomethaemoglobin method. The platelet count was obtained using the haemocytometer. 
2.7 Data Analysis and Statistical Procedures

Statistical analysis of the data was carried out with SPSS version 22.0 using One Way Analysis of Variance (ANOVA). The statistically analyzed data were reported as Mean \pm SD. Significant difference was accepted at $95 \%$ confidence level of probability i.e. if $P<0.05$.

\section{Results}

\subsection{Effect of Dichlorvos on Aspartate Transaminase Activity (IU/L) in Wistar Rats}

The result below shows there is non-significant decrease $(\mathrm{P}<0.05)$ when group $6(36.17 \pm 9.39)$ is compared with group $1(42.06 \pm 4.34)$, group $2(38.83 \pm 6.26)$, group $3(47.83 \pm 0.92)$, group 4 (43.67 \pm 6.08$)$ and group $5(36.22 \pm 8.24)$.

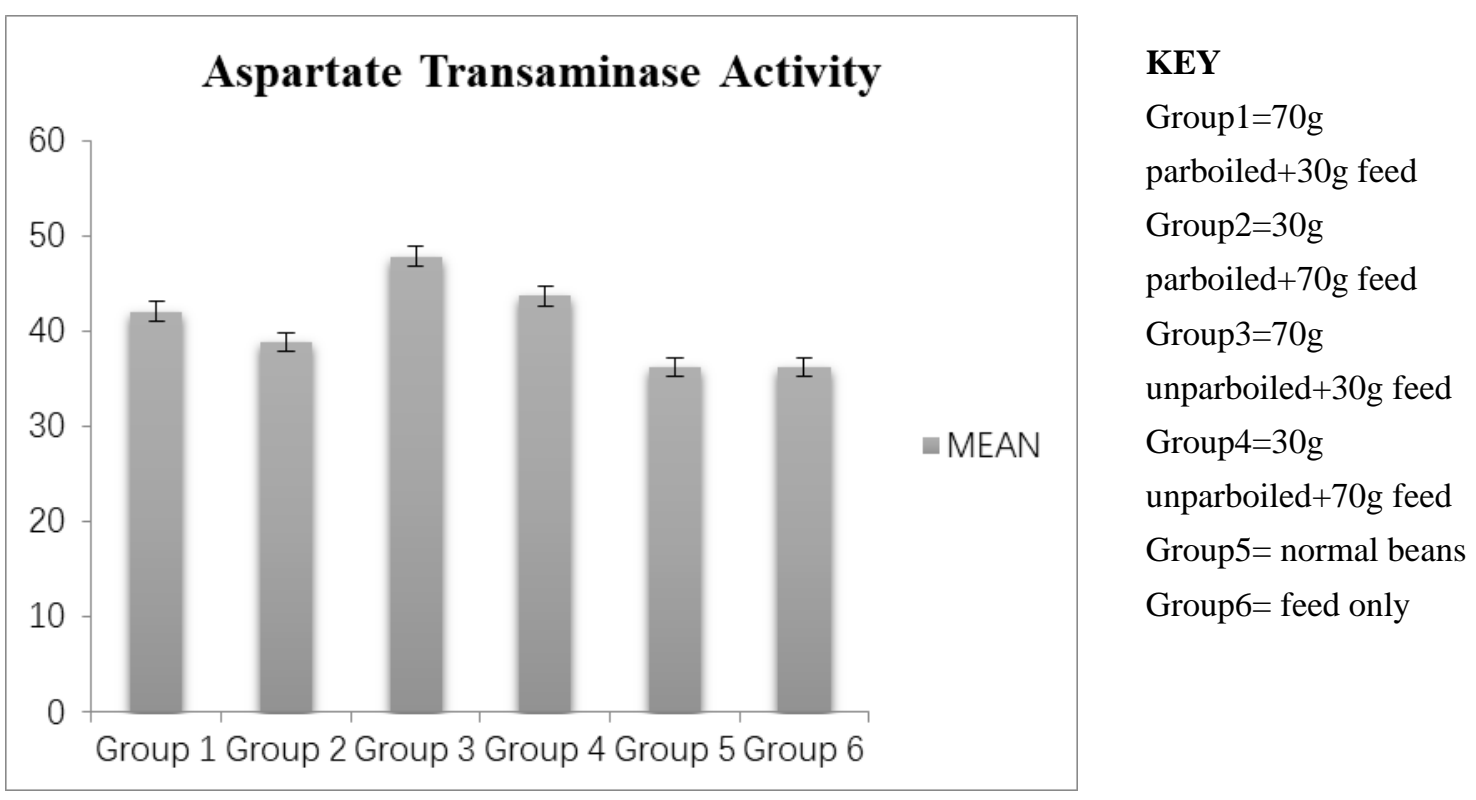

Figure 3.1. Activity of aspartate transaminase in Wistar rats of different groups

\subsection{Effect of Dichlorvos on Alanine Amino Transferase Activity (IU/L) in Wistar Rats}

From the chart above, there is a non-significant $(\mathrm{P}<0.05)$ decrease in the ALT activity when group $6(136.33 \pm 21.98)$ is compared to group $5(144.78 \pm 14.45)$, group $1(161.33 \pm 2.52)$ and group $2(148 \pm 17.51)$. But the comparison of group 6 to group $3(178.33 \pm 14.19)$ and group 4 (168.56 \pm 3.62$)$ shows a significant decrease. 


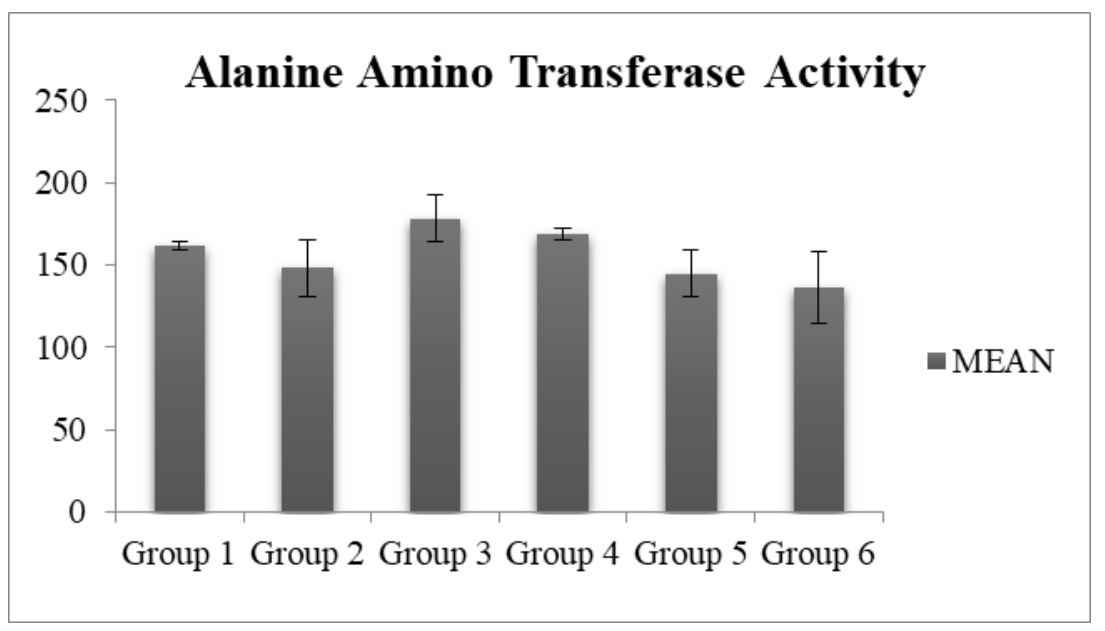
KEY
Group1=70g
parboiled $+30 \mathrm{~g}$ feed
Group2=30g
parboiled $+70 \mathrm{~g}$ feed
Group3=70g
unparboiled $+30 \mathrm{~g}$ feed
Group4=30g
unparboiled $+70 \mathrm{~g}$ feed
Group5= normal beans
Group6= feed only

Figure 3.2. Activity of alanine amino transferase in Wistar rats of different groups

\subsection{Effect of Dichlorvos on Alkaline Phosphatase Activity (IU/L) in Wistar Rats}

From the chart above, the result of group $6(9.07 \pm 0.38)$ shows a significant decrease $(\mathrm{P}<0.05)$ when compared to group $3(13.41 \pm 1.17)$ but shows a non-significant decrease when group 6 is compared to group $1(11.02 \pm 0.68)$, group 2 (10.87 \pm 0.27$)$, group $4(11.09 \pm 0.98)$ and group $5(10.02 \pm 0.72)$.

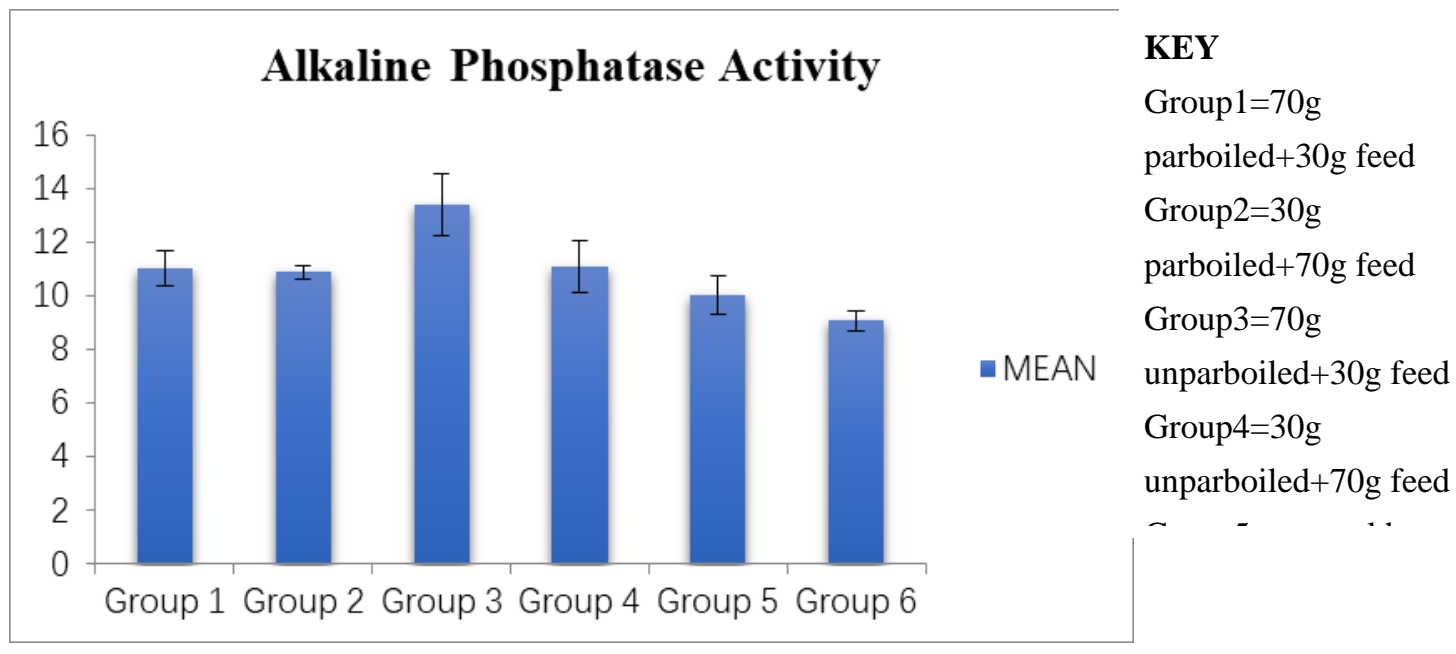

Figure 3.3. Activity of alkaline phosphatase in Wistar rats of different groups

\subsection{Effect of Dichlorvos on Serum Glutathione Activity in Wistar Rats}

From the chart above, there is significant $(\mathrm{P}<0.05)$ increase when group $6(9.87 \pm 0.46)$ is compared to group $3(5.97 \pm 0.49)$ and group $4(6.3 \pm 0.36)$ but a non-significant $(\mathrm{P}<0.05)$ increase is seen when group 6 is compared to group $1(8.28 \pm 0.38)$, group $2(7.21 \pm 0.28)$ and group $5(8.52 \pm 0.62)$. 


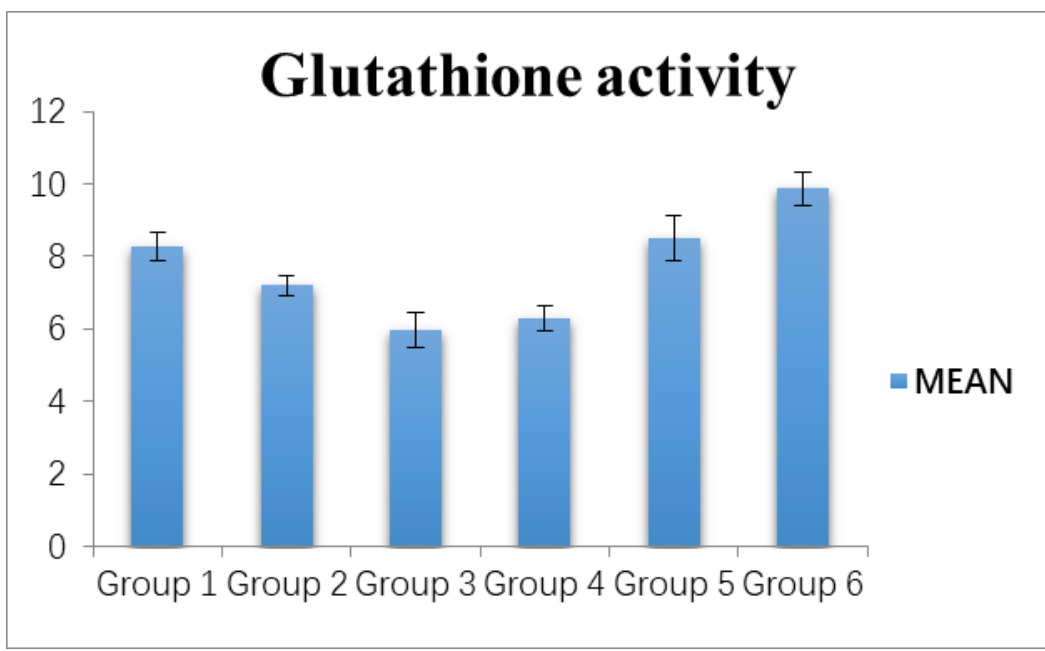

\section{KEY}

Group $1=70 \mathrm{~g}$

parboiled $+30 \mathrm{~g}$ feed

Group2 $=30 \mathrm{~g}$

parboiled $+70 \mathrm{~g}$ feed

Group $3=70 \mathrm{~g}$

unparboiled $+30 \mathrm{~g}$ feed

Group4 $=30 \mathrm{~g}$

unparboiled $+70 \mathrm{~g}$ feed

Figure 3.4. Serum glutathione activity in Wistar rats of different groups

\subsection{Effect of Dichlorvos on Serum Glutathione Peroxidase Activity in Wistar Rats}

From the chart above, the comparisons of group $6(4.30 \pm 0.12)$ to group 5 (3.80 \pm 0.17$)$, group $2(3.15 \pm 0.25)$ and group $1(3.34 \pm 0.14)$ show a non-significant $(\mathrm{P}<0.05)$ increase but when group 6 is compared to group $3(1.52 \pm 0.12)$ and group $4(2.20 \pm 0.16)$, it shows a significant $(\mathrm{P}<0.05)$ increase.

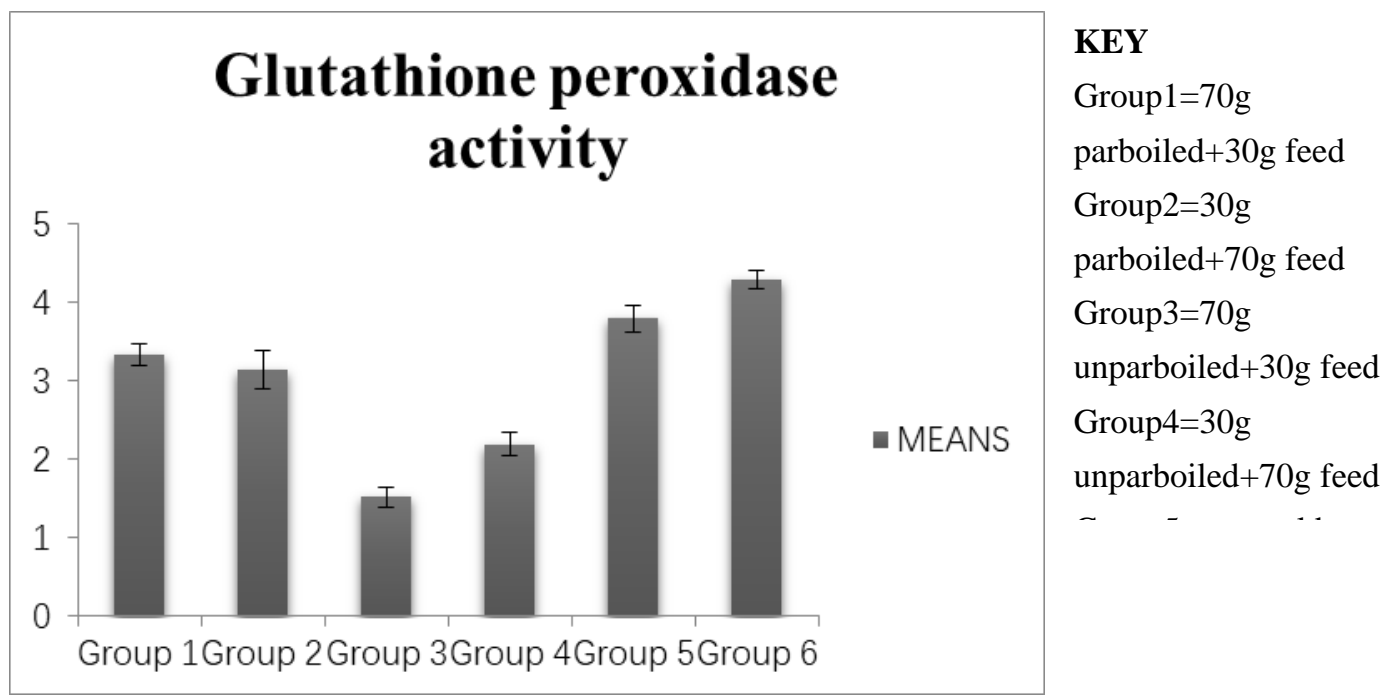

Figure 3.5. Serum glutathione peroxidase activity in Wistar rats of different groups

\subsection{Effect of Dichlorvos on Serum Catalase Concentratioin Wistar Rats}

The chart below shows a significant $(\mathrm{P}>0.05)$ increase when group $6(1.06 \pm 0.08)$ is compared to group $1(0.63 \pm 0.05)$, group $3(0.53 \pm 0.05)$ and group $4(0.62 \pm 0.04)$ but shows a non-significant increase when compared to group $2(0.81 \pm 0.03)$ and group $5(0.94 \pm 0.58)$. 


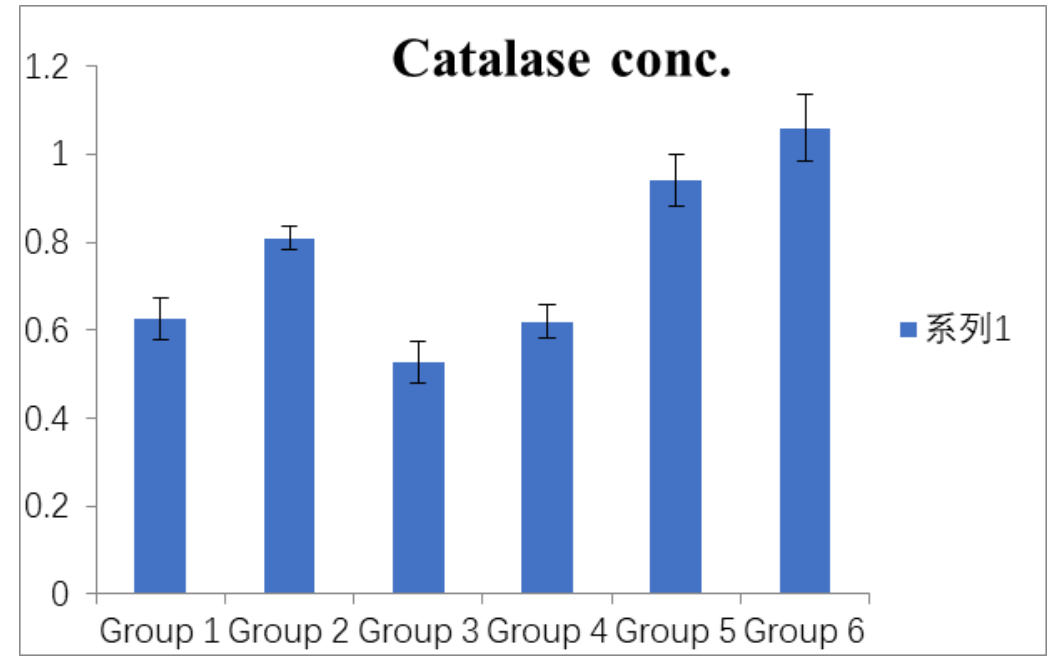

\section{KEY}

Group1=70g

parboiled $+30 \mathrm{~g}$ feed

Group2=30g

parboiled $+70 \mathrm{~g}$ feed

Group3=70g

unparboiled $+30 \mathrm{~g}$ feed

Group4=30g

unparboiled $+70 \mathrm{~g}$ feed

Figure 3.6. Serum catalase activity in Wistar rats of different groups

\subsection{Effect of Dichlorvos on Serum Superoxide Dismutase Activity in Wistar Rats}

From the chart below, the comparison of group $6(11.02 \pm 0.04)$ to group $1(10.69 \pm 0.04)$, group $3(10.43 \pm 0.05)$ and group $4(10.59 \pm 0.05)$ shows a significant $(\mathrm{P}<0.05)$ increase but shows a non-significant $(\mathrm{P}<0.05)$ increase when compared to group $2(10.79 \pm 0.05)$ and group $5(10.99 \pm 0.03)$.

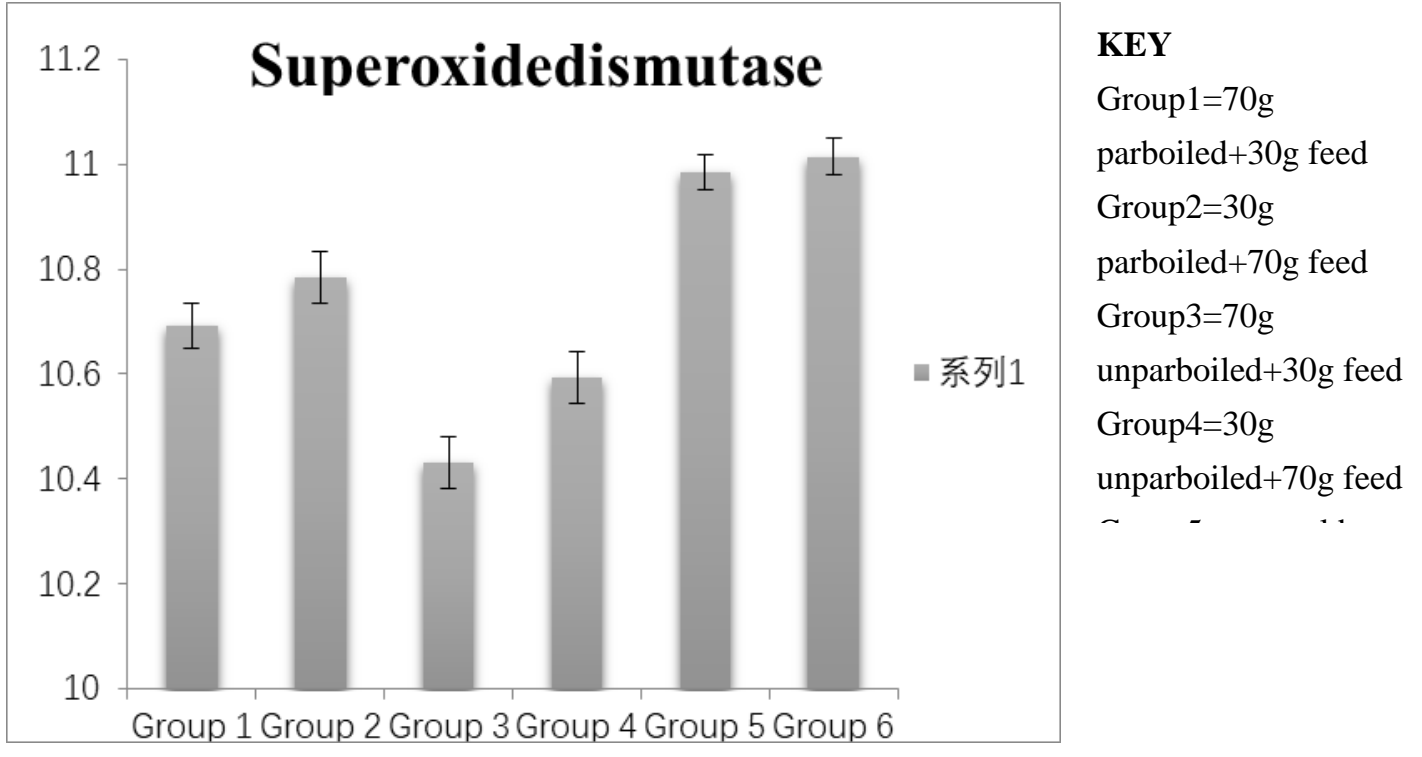

Figure 3.7. Serum superoxide dismutase activity in Wistar rats of different groups

\subsection{Effect of Dichlorvos on Serum Malondialdehyde Concentration in Wistar Rats}

From the chart above, there is non-significant $(\mathrm{P}<0.05)$ decrease in concentration of malondialdehyde when group $6(0.62 \pm 0.07)$ is compared to group $1(0.85 \pm 0.05)$, group 2 $(0.87 \pm 0.06)$ and group $5(0.80 \pm 0.05)$. But a significant decrease $(\mathrm{P}<0.05)$ is seen when group 6 is compared to group $3(1.49 \pm 0.03)$ and group $4(1.08 \pm 0.04)$. 


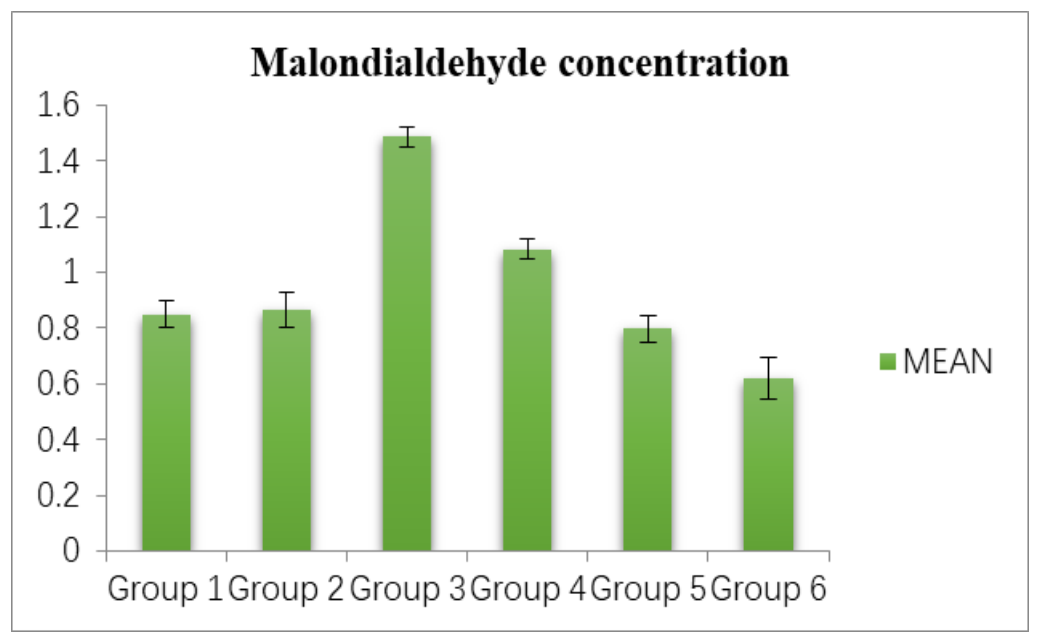

KEY

Group1=70g

parboiled $+30 \mathrm{~g}$ feed

Group2=30g

parboiled $+70 \mathrm{~g}$ feed

Group3=70g

unparboiled $+30 \mathrm{~g}$ feed

Group4=30g

unparboiled $+70 \mathrm{~g}$ feed

Figure 3.8. Serum total Malondialdehyde concentration in Wistar rats of different

\subsection{Effect of Dichlorvos on Serum Urea Concentration ( $\mathrm{mg} / \mathrm{dl}$ ) in Wistar Rats}

The result of figure 4.9 shows significant $(\mathrm{P}<0.05)$ decrease when group $6(57.66 \pm 2.34)$ is compared to group $3(97.50 \pm 2.28)$, but a non-significant decrease when compared with group 5 (70.96 \pm 1.13$)$, group 4 (87.20 \pm 3.77$)$, group $2(85.40 \pm 2.14)$ and group $1(87.01 \pm 0.55)$.

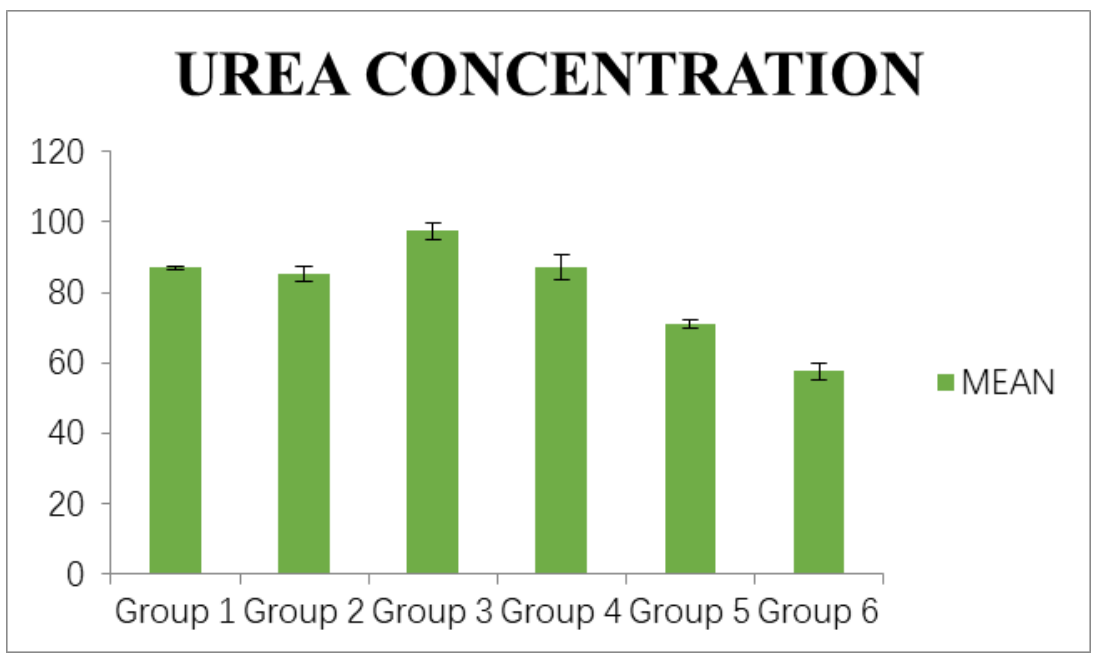

\section{KEY}

Group1=70g parboiled $+30 \mathrm{~g}$ feed Group2=30g parboiled $+70 \mathrm{~g}$ feed Group3=70g unparboiled $+30 \mathrm{~g}$ feed Group4=30g unparboiled $+70 \mathrm{~g}$ feed

Figure 3.9. Serum urea concentration in Wistar rats of different groups

\subsection{Effect of Dichorvos on Serum Total Protein Concentration (g/dl) in Wistar Rats}

The result for total protein shows that when group $6(4.44 \pm 0.02)$ is compared to group 5 (4.94 \pm 0.05$)$, group $1(4.74 \pm 0.05)$ and group $3(4.64 \pm 0.02)$, a significant decrease was seen but when compared to group $2(4.56 \pm 0.03)$ and group $4(4.54 \pm 0.02)$, a non-significant $(\mathrm{P}<0.05)$ decrease is seen. 


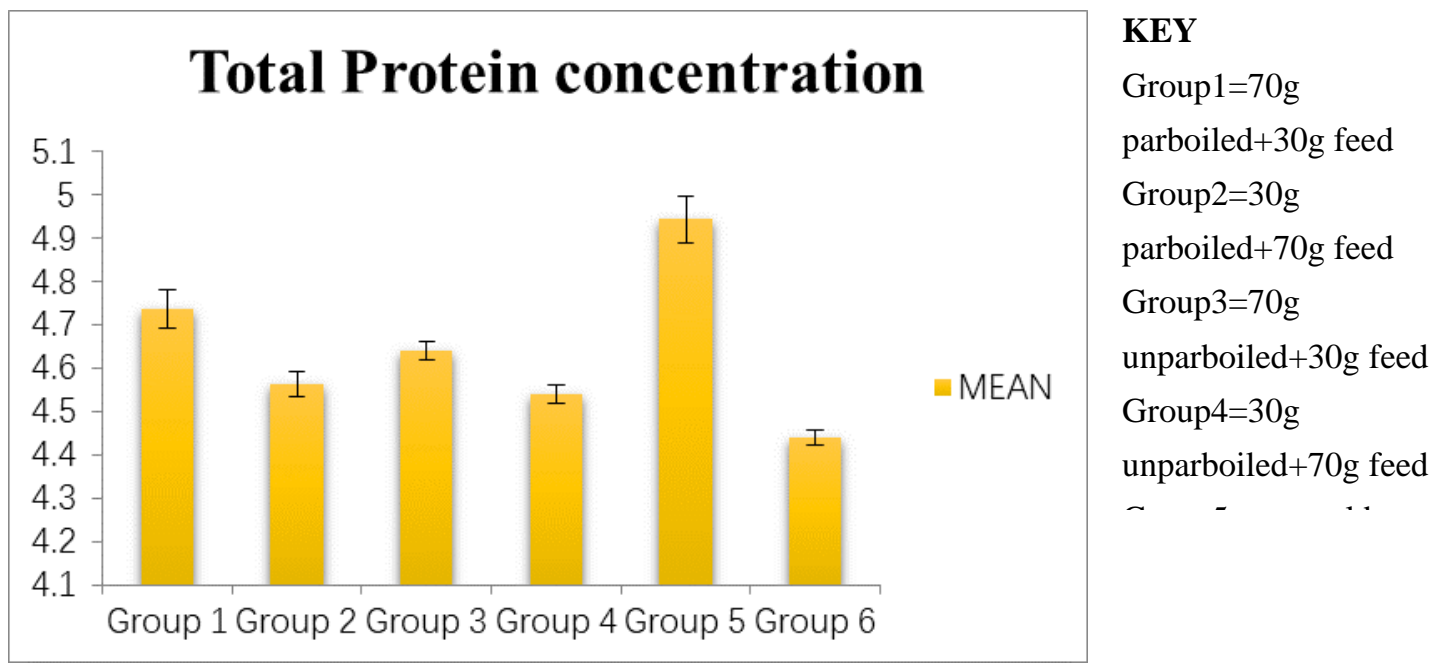

Figure 3.10. Serum total protein concentration in Wistar rats of different groups

\subsection{Effect of Dichlorvos on Total Bilirubin Concentration $(\mathrm{g} / \mathrm{dl})$ in Wistar Rats}

From the chart above, there is a significant $(\mathrm{P}<0.05)$ decrease when group $6(1.27 \pm 0.09)$ is compared to group $4(2.33 \pm 0.20)$, group $3(2.50 \pm 0.10)$, and group $1(1.83 \pm 0.15)$, but a non-significant $(\mathrm{P}<0.05)$ decrease when compared to group $5(1.44 \pm 0.15)$ and group 2 $(1.50 \pm 0.10)$.

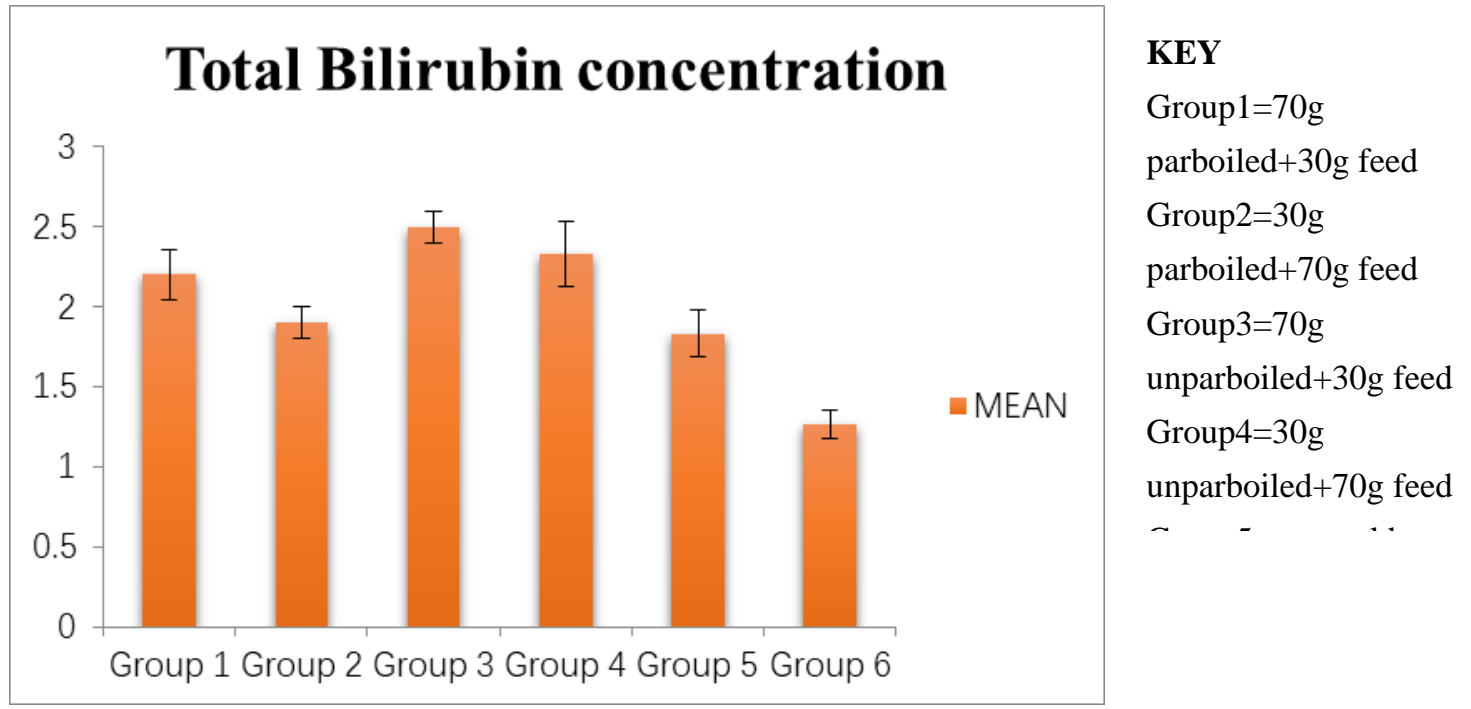

Figure 3.11. Serum total bilirubin concentration in Wistar rats of different groups

\subsection{Effect of Dichlorvos on Serum Direct Bilirubin Concentration in Wistar Rats}

The chart above shows a significant $(\mathrm{P}<0.05)$ decrease when group $6(0.70 \pm 0.10)$ is compared to group $2(1.23 \pm 0.15)$, group $4(1.43 \pm 0.40)$, group $3(1.63 \pm 0.12)$ and group 1 $(1.27 \pm 0.15)$. But group 6 shows a non-significant $(\mathrm{P}<0.05)$ decrease when compared to group $5(0.93 \pm 0.15)$. 


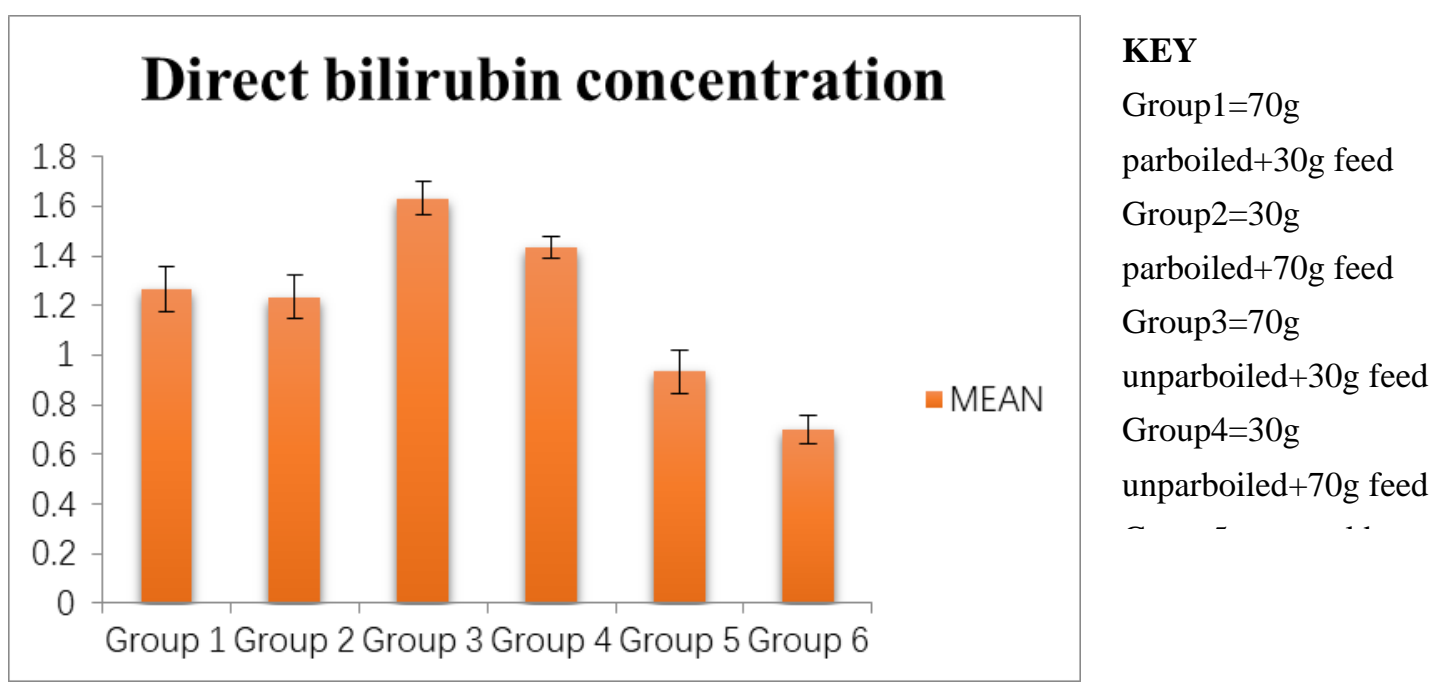

Figure 3.12. Serum direct bilirubin concentration in Wistar rats of different groups 
Table 1. Haematological Parameters

\begin{tabular}{|c|c|c|c|c|c|}
\hline Groups & WBC & PLATELET & PCV & $\mathbf{H b}$ & RBC \\
\hline $\begin{array}{c}\text { Group } \\
1\end{array}$ & $\begin{array}{c}6933.33 \pm \\
133.33^{\mathrm{a}}\end{array}$ & $\begin{array}{c}98.33 \pm \\
1.67^{\mathrm{a}}\end{array}$ & $\begin{array}{c}37.66 \\
\pm 0.88^{\mathrm{b}}\end{array}$ & $\begin{array}{c}12.63 \pm \\
0.20^{\mathrm{a}}\end{array}$ & $110.00 \pm 5.77^{a}$ \\
\hline $\begin{array}{c}\text { Group } \\
2\end{array}$ & $6333.33 \pm 176.38^{a}$ & $\begin{array}{l}100.00 \\
\pm 5.77^{\mathrm{a}}\end{array}$ & $\begin{array}{c}43.00 \\
\pm 0.57^{\mathrm{cd}}\end{array}$ & $\begin{array}{l}14.63 \pm \\
0.38^{\mathrm{bc}}\end{array}$ & $110.00 \pm 5.77^{a}$ \\
\hline $\begin{array}{c}\text { Group } \\
3\end{array}$ & $6733.33 \pm 371.18^{a}$ & $\begin{array}{r}96.66 \\
\pm 6.67^{\mathrm{a}}\end{array}$ & $\begin{array}{r}43.00 \pm \\
1.53^{\mathrm{cd}}\end{array}$ & $\begin{array}{l}13.96 \pm \\
0.38^{\mathrm{bc}}\end{array}$ & $95.00 \pm 2.89^{\mathrm{a}}$ \\
\hline $\begin{array}{c}\text { Group } \\
4\end{array}$ & $6533.33 \pm 133.33^{a}$ & $\begin{array}{l}110.00 \\
\pm 5.77^{\mathrm{a}}\end{array}$ & $\begin{array}{c}44.66 \\
\pm 1.33^{\mathrm{d}}\end{array}$ & $\begin{array}{c}14.86 \pm \\
0.43^{\mathrm{c}}\end{array}$ & $96.67 \pm 8.82^{\mathrm{a}}$ \\
\hline $\begin{array}{c}\text { Group } \\
5\end{array}$ & $6266.66 \pm 240.37^{a}$ & $\begin{array}{l}105.00 \\
\pm 7.63^{\mathrm{a}}\end{array}$ & $\begin{array}{r}40.00 \\
\pm 1.15^{b c}\end{array}$ & $\begin{array}{c}13.63 \pm \\
0.20^{\mathrm{b}}\end{array}$ & $106.67 \pm 6.67^{a}$ \\
\hline $\begin{array}{c}\text { Group } \\
6\end{array}$ & $6600.00 \pm 115.47^{\mathrm{a}}$ & $\begin{array}{l}128.33 \\
\pm 4.41^{\mathrm{b}}\end{array}$ & $\begin{array}{l}45.66 \\
\pm 1.45^{\mathrm{d}}\end{array}$ & $\begin{array}{c}14.96 \pm \\
0.20^{\mathrm{c}}\end{array}$ & $105.00 \pm 2.89^{a}$ \\
\hline
\end{tabular}

\begin{tabular}{cccc}
\hline Groups & MCHC & MCV & MCH \\
\hline Group 1 & $33.539 \pm 0.17^{\mathrm{bc}}$ & $0.00034 \pm 0.00^{\mathrm{a}}$ & $0.00011 \pm 0.00^{\mathrm{a}}$ \\
Group 2 & $34.023 \pm 0.04^{\mathrm{cd}}$ & $0.00039 \pm 0.00^{\mathrm{b}}$ & $0.00013 \pm 0.00^{\mathrm{b}}$ \\
Group 3 & $32.488 \pm 0.25^{\mathrm{a}}$ & $0.00045 \pm 0.00^{\mathrm{c}}$ & $0.00015 \pm 0.00^{\mathrm{c}}$ \\
Group 4 & $33.289 \pm 0.07^{\mathrm{ab}}$ & $0.00046 \pm 0.00^{\mathrm{d}}$ & $0.00015 \pm 0.00^{\mathrm{c}}$ \\
Group 5 & $34.075 \pm 0.06^{\mathrm{d}}$ & $0.00037 \pm 0.00^{\mathrm{e}}$ & $0.00013 \pm 0.00^{\mathrm{b}}$ \\
Group 6 & $32.779 \pm 0.07^{\mathrm{bc}}$ & $0.00043 \pm 0.00^{\mathrm{f}}$ & $0.00013 \pm 0.00^{\mathrm{b}}$ \\
\hline
\end{tabular}

abcd Groups with different superscript are significantly $(p<0.05)$ different when compared along the column. 


\section{Discussion}

Dichlorvos has become one of the most commonly used organophosphate pesticides in agricultural preservation process especially for stored products (13). Although being classified as a probable human carcinogen by the Environmental Protection Agency (30), the relevance of dichlorvos in agriculture has made it an indispensable pesticide in the storage of agricultural products. The toxicological and hematological effects of consuming parboiled and un-parboiled beans treated with dichlorvos were evaluated.

Liver enzymes ALT, AST and ALP are employed in the evaluation of hepatic disorders and as such, an aberration in activity of these enzymes is a reflection of the liver's integrity and a high value is an indicator of inflammatory hepatocellular disorders (31).

A non-significant increase $(\mathrm{P}<0.05)$ was seen in the aspartate transaminase (AST) enzyme when the treatment groups were compared to the control (group 6) which may not be used to mainly evaluate the hepatocyte injury since it is primarily a mitochondrial enzyme and can be found in the heart, muscle, kidney and brain; hence, the concentration of alanine transaminase (ALT) in the blood was evaluated and the treatment groups showed an increase in concentration when compared to the control (group 6); a non-significant increase for group 1 , group 2 and group 4 while group 3, being the group containing un-parboiled beans of high concentration of dichlorvos showed a significant $(\mathrm{P}<0.05)$ increase. Alkaline phosphatase (ALP) showed a similar result with ALT where group 3 showed a significant increase while the other treatment groups showed a non-significant $(\mathrm{P}<0.05)$ increase. This could be due to the cytoplasmic nature of these enzymes, upon liver injury they enter into the circulatory system as a result of alteration of membrane permeability. The report on the non-significant increase of liver enzymes is supported by Yang et al., (2012) (32), Chavarri et al., (2005) (33) and Kaushik et al., (2009) (34). The increase in the levels of the liver enzymes in the blood was dose dependent, but the significant increase of ALT in group 3 could be a reflection of the importance of parboiling since the normal washing of the beans could have reduced the concentration of dichlorvos pesticide but did not remove it completely (35), (36). Residues of the dichlorvos could cause hepato-toxicity through the generation of free radicals, hence the degeneration of the liver cells as a result of oxidative stress. The non-significant increase of group 1 (the group containing parboiled beans of high concentration of dichlorvos) could be showing the effect of washing and parboiling of beans on the concentration of the pesticide; implying that the pesticide was reduced (37) and liver being the site of biotransformation could have transformed the toxic compound into an inactive metabolite thus reducing its toxicity (38). The proliferation of the free radicals could be as a result of the reduction of antioxidants which mops up the free radicals.

Obvious facts through research have shown the great importance of CAT, SOD, GSH and MDA as biological indicators of the antioxidant capacity of the body resulting in protection against damages usually elicited through oxidative stress.

In this study, alterations of the antioxidant (SOD, CAT, GSH and GPx) capacity of the body system and lipid peroxidation marker following the different methods of beans preparation were investigated. The reduction in antioxidant enzymes was significant $(\mathrm{p}<0.05)$ for the 
un-parboiled groups which is a likely indication of the ability of the compound to generate free radicals which are concomitantly mopped up by the antioxidants present in the body. This was corroborated by the increase in lipid peroxidation marker, MDA at same point.

The increase in lipid peroxidation was accompanied by a significant reduction in the GSH level. GSH is a tripeptide found in many mammalian tissues and is a very necessary free-radical scavenger. It has been shown that certain environmental toxicants can elicit oxidative stress by converting the parent compound to its reactive metabolites (39). GSH decrease indicates that there is an increase in the levels of ROS generated in the cell (40) thereby leading to increased oxidative stress. Reduction in the GSH level may be due to indirect conjugation with excess electrophiles produced since dichlorvos is an electrophilic compound (41). Glutathione peroxidase (GPx) was found to be significantly decreased in the rats that received un-parboiled beans whereas its activity was non-significantly elevated in the groups that received parboiled beans. GPx, an important intracellular enzyme depending mostly on a micronutrient cofactor - selenium, is responsible for the breakdown of hydrogen peroxides $\left(\mathrm{H}_{2} \mathrm{O}_{2}\right)$ to water; and lipid peroxides to their corresponding alcohols mainly in the mitochondria and in some cases, in the cytosol (42). Thus, GPx plays a more crucial role of inhibiting lipid peroxidation process, protecting cells from oxidative stress (43). The reduction of CAT and SOD activities may be due to the rapid proliferation of superoxide anions and hydrogen peroxide radicals after consumption of dichlorvos contaminated beans. The decreased activities of SOD and CAT is previously reported in rats exposed to dichlorvos by Ojo (44) and Sharma (41) unlike the reports of Kanu (45), Dwivedi (20) and Edem (21) were the antioxidant enzymes were reported to have increased. There was a slight increase in the Malondealdehyde (MDA) levels which is a biomarker for lipid peroxidation (LPO) although the increase was not significant in the parboiled groups but showed a significant increase in the un-parboiled groups. This result implies that the altered antioxidant enzymes' activities could have given rise to the infiltration of free radicals into the cells. Hence, the parboiling of the beans may further reduce the concentration of pesticide residues deposited on the beans thereby reducing lipid peroxidation.

The significant increase in the concentration of urea in the blood of group 3 rats could be as a result of lesion in the kidney as a result of oxidative stress accumulated from the reactive oxygen species; this might also have resulted not only because this group was fed with un-parboiled beans but also considering the concentration of dichlorvos that was used to treat the beans. This assertion is made owing to the fact that group 4 rats showed a non-significant decrease like the rats fed with parboiled beans. The blood urea can be increased in all types of kidney impairments such as hydronephrosis, congenital cystic, kidney renal tuberculosis, condition in which deposition of calcium occurs as hypervitaminosis D (46).

Proteins are the fundamental components of all living cells and include many substances such as enzymes, hormones and antibodies that are necessary for the proper functioning of an organism (47). Serum protein has many functions including transport of other substances, immune defense, blood clotting and inflammation defense. Serum protein levels and assays are useful in evaluating nutrition status, infection and various disorders (48) as well as indicator for assessing the total amount of protein in the blood plasma or serum and studies 
have shown that its depletion is more of a common presentation of chronic liver diseases. The results on the total protein show a significant increase in group 1 rats and group 3 rats when compared to group 6 rats and non-significant increase was seen in group 2 rats and group 4 rats. This could be as a result of the high protein content of beans (49), (50). Increased release of enzymes by the damaged tissues and the antibodies to counteract the dichlorvos might also be the cause of increase in serum protein. Since the body on perceiving the presence of dichlorvos as being injurious, there will be a release of antibodies which are composed of proteins hence leading to increased total protein in the serum.

Researches by Binukumar (13), Banerjee (51), Kovacic, (52), Vidyasagar (53) has shown that the basis of organophosphate toxicity in the production of oxidative stress may be due to changes in normal antioxidant homeostasis resulting in antioxidant depletion if the requirement of continuous antioxidants is not maintained. Also, dichlorvos has been reported to play roles in the liver dysfunction of animals exposed to it (54) which is majorly linked to the activities of reactive oxygen species (ROS) (13), (55). This could be the reason why there were increase in the concentration of both total bilirubin and direct bilirubin although total bilirubin concentration of group 2 rats was non-significant because it is the group fed with the parboiled beans of low concentration of dichlorvos implying that the result was dose-dependent. With the increase in the liver transaminases, ALP and total bilirubin, it could be said that the integrity of the liver has been compromised through oxidative damage due to the consumption of dichlorvos. Bilirubin has been shown to be a natural antioxidant (56). As an antioxidant, bilirubin demonstrated anti-atherogenic function through inhibition of low-density lipoprotein oxidation (57) or through inhibition of vascular endothelial activation, which may mediate the anti-atherogenic properties of heme oxygenase-1 (58). The significant increase seen in this study suggests that dichlorvos caused a leakage of bilirubin as a result of the damage of liver cells.

The concentration of red blood cell (RBC) decreased for the un-parboiled groups and non-significantly increased for the parboiled groups. This could have resulted from the levels of reactive oxygen species generated in the in the mitochondria and released into the blood because of the imbalance between reactive oxygen species (45), (59). The reduction in RBC could suggest an anaemic condition and haemoglobin $(\mathrm{Hb})$ levels of the rats fed with the un-parboiled beans could have risen from low supply of oxygen to the tissues as a result of possible disruption of the electron transport system by high concentration of dichlorvos. Mean corpuscular haemoglobin $(\mathrm{MCH})$ was observed to be significantly reduced in the group fed with un-parboiled beans. This finding suggests possible inhibitory effect of dichlorvos on heme synthesis which is indicative of symptomatic anaemic condition. Also, the significant decrease of MCHC and a non-significant decrease of MCV in group 3 show hypochromic microcytic anaemia. In the report of the research carried out by Akomas et al., 2014 (60), it was observed that there was the development of hypochromic anaemia due to a fall in the iron content of the body resulting from oxidative stress. The elevation in the white blood cells (WBC) of group 1 rats and group 3 rats suggest physiological inflammatory response as a result of tissue damage and inflammation causing acceleration of the immune system to increase production of white blood cells (61). 


\section{Conclusion}

In summary, this work points out the need for beans consumers to always ensure that beans is thoroughly washed and parboiled in the course of beans preparation - an information that should be disseminated by both public and private health agencies. Since parboiling is not complete cooking and different dishes prepared with beans does not encourage parboiling of beans for example making beans balls (akara), beans could be thoroughly washed with hot water. From this study, the integrity of the liver and kidney were in doubt sequel to the consumption of high dose of DDVP-treated beans. However, group 3 rats showing a significant increase in the activities of alanine amino transferase and alkaline phosphatase enzymes indicates the need to parboil beans since group 1 rats showed no significance, implying that parboiling of the beans can reduce the concentration of the pesticide hence, reducing the toxicity of the dichlorvos. Knowing that major basis of toxicity of dichlorvos is the generation of free radicals and if the concentration is reduced, generation of free radicals by dichlorvos is reduced.

\section{References}

Akomas S. C., Okafor A. I., \& Ijioma S. N. (2014). Glucose level, Haematological parameters and lipid profile in Ficus. sur treated diabetic rats. Compr. J. Agric. Biol. Sci., 2, 5-11.

Alayande, L. B., Mustapha, K. B., Dabak, J. D., \& Ubom, G. A. (2012). Comparison of nutritional values of brown and white beans in Jos North Local Government markets. African Journal of Biotechnology, 11(43), 10135-10140. https://doi.org/10.5897/AJB11.3908

Alia, M., Horcajo, C., Bravo, L., \& Goya, L. (2003). Effect of grape antioxidant dietary fiber on the total antioxidant capacity and the activity of liver antioxidant enzymes in rats. Nutrition Research, 23, 1251-1267. https://doi.org/10.1016/S0271-5317(03)00131-3

Amin, K. A., Abdel, H. H., \& Abd Elsttar, A. H. (2010). Effect of food azo dyes Tartrazine and carmoisine on biochemical parameters related to renal, hepatic function and oxidative stress biomarkers in young male rats. Food and Chemical Toxicology, 48, 2994-2999. https://doi.org/10.1016/j.fct.2010.07.039

Angel, Y., Jong-Hyouk, P., Abd El-Aty, A. M., Jeong-Heui, C., Jae-Ho, O., Kisung, K., ... Jung-Ah, D. (2012). Synergistic effect of washing and cooking on the removal of multi-classes of pesticides from various food samples. Food Control., 25, 99-105. https://doi.org/10.1016/j.foodcont.2012.04.018

Animasaun, D. A., Oyedeji, S., Azeez, Y. K., Mustapha, O. T., \& Azeez, M. A. (2015). Genetic variability study among ten cultivars of cowpea (Vigna unguiculata L. Walp) using morpho-agronomic traits and nutritional composition. Journal of Agric Sci., 10, 119-130.

Arthur, J. R., \& Boyne, R. (1985). Superoxide dismutase and gluthathione peroxidase in neutrophils from selenium deficient and copper deficient cattle. Life Science, 36, 1596. https://doi.org/10.1016/0024-3205(85)90381-9 
Banerjee, B. D., Seth, V., Bhattacharya, A., \& Chakraborty, A. K. (1999). Biochemical effects of some pesticides on lipid peroxidation and free-radical scavengers. Toxicol. Lett. 107, 33-47. https://doi.org/10.1016/S0378-4274(99)00029-6

Binukumar, B. K., Bal, A., Kandimalla, R., Sunkaria, A., \& Gill, K. D. (2010). Mitochondrial energy metabolism impairment and liver dysfunction following chronic exposure to dichlorvos. Toxicology, 270(2-3), 77-84. https://doi.org/10.1016/j.tox.2010.01.017

Bui-Nguyen, T. M., Baer, C. E., \& Lewis, J. A. (2015). Dichlorvos exposure results in large scale disruption of energy metabolism in the liver of the zebrafish, Danio rerio. BMC Genomics, 16, 853. https://doi.org/10.1186/s12864-015-1941-2

Castro MFPM de Oliveira, J. J., Rodrigues, J., Loredo, I. S. D., \& Liveira, J. J. (2002). Highley EA. Study on the persistence of trifluralin, chlorpyrifos, decamethrin, cypermethrin, dichlorvos in rice, beans after cooking in a commercial microwave oven. In: Credland PF, Armitage DM, Bell CH, Cogan PM., editors. Advances-In-Stored-Product-Protection. NY, USA: Proceedings of the 8th international working conference on stored product protection. pp. 517-21. https://doi.org/10.1079/9780851996912.0517

Chavarri, M. J., Herrera, A., \& Arino, A. (2005). The decrease in pesticides in fruits and vegetables during commercial processing. International journal of food science technology, 40, 205-11. https://doi.org/10.1111/j.1365-2621.2004.00932.x

Dwivedi, N., \& Flora, S. J. (2015). Sub-chronic exposure to arsenic and dichlorvos on erythrocyte antioxidant defense systems and lipid peroxidation in rats. Journal of Environmental Biology, 36(2), 383-91.

Edem, V. F., Kosoko, A., Akinyoola, S. B., Owoeye, O., Rahamon, S. K., \& Arinola, O. G. (2012). Plasma antioxidant enzymes, lipid peroxidation and hydrogen peroxide in wistar rats exposed to Dichlorvos insecticide. Arch. Appl. Sci. Res., 4, 1778-1781.

Egho, E. O., \& Enujeke, E. C. (2012). Minimising Insecticide Application in the Control of Insect Pests of Cowpea (Vigna Unguiculata (L) WALP) in Delta State, Nigeria. Sustainable Agriculture Research Journal, 1(1). https://doi.org/10.5539/sar.v1n1p87

Elhardallou, S., Khalid, II, Gobouri, A. A., \& Abdel-Hafez, S. H. (2015). Amino acid composition of cowpea (Vigna ungiculata L. Walp) flour and its protein isolates. Food and Nutrition Sciences, 6(9), 790-797. https://doi.org/10.4236/fns.2015.69082

EPA, (Environmental Protection Agency). Dichlorvos. (2000). Available from: http://www3.epa.gov. [Last accessed on 2015 Oct 21].

Exner, R., Wessner, B., Manhart, N., \& Roth, E. (2000). Therapeutic potential of glutathione. Wiener. Klinishe Wochenschr, 112, 610-616.

Fatimah, A. A., \& Omaima, M. M. H. (2016). Histopathological and biochemical studies in male Wistar albino rats injected with diethylnitrosamine and treated with Camel's milk and Curcuma longa. Egypt Journal of Chemistry Environmental Health, 2(2), 548-565 


\section{Macrothink}

Journal of Biology and Life Science

ISSN 2157-6076

2020, Vol. 11, No. 1

Frota, K. M. G., Mendonca, S., Saldiva, P. H. N., Cruz, R. J., \& Areas, J. A. G. (2008). Cholesterol-lowering properties of whole cowpea seed and its protein isolate in hamsters. $\begin{array}{llll}\text { Journal of } & \text { Food } & \text { Science, } & \text { 73(9), }\end{array}$ https://doi.org/10.1111/j.1750-3841.2008.00953.x

Geetanjali, K., Santosh, S. S., \& Naik, N. (2009). Food processing a tool to pesticide residue dissipation-A review. Food Research International Journal, 42, 26-40. https://doi.org/10.1016/j.foodres.2008.09.009

Gill, S. S., \& Tuteja, N. (2010). Reactive oxygen species and antioxidant machinery in abiotic stress tolerance in crop plants. Plant Physiology and Biochemistry, 48(12), 909-30. Epub 2010 Sep. 15. https://doi.org/10.1016/j.plaphy.2010.08.016

Góth, L., Rass, P., \& Pay, A. (2004). Catalase enzyme mutations and their association with diseases. Molecular. Diagnosis. 8, 141-149. https://doi.org/10.1007/BF03260057

Harlin, K. S., \& Dellinger, J. A. (1993). Retina, brain and blood cholinesterase levels in cats treated with oral dichlorvos. Journal of vertinary toxicology, 35, 201-203.

Helal, G. E., Zaahkouk, A. M., \& Mekkaway, A. H. (2000). Effect of Some Food Colourants (Synthetic and Natural Products) of Young Albino Rats. Egyptian Journal of Hospital Medicine, 1(2), 103-113.

Hodgson, E. A. (2004). Textbook of Modern Toxicology. 3rd ed. New Jersey: John Wiley and Sons, Inc. https://doi.org/10.1002/0471646776

Kanu, K. C., Solomon, I., \& Odudu, A. (2016). Haematological, Biochemical and Antioxidant Changes in Wistar Rats Exposed to Dichlorvos Based Insecticide Formulation Used in Southeast Nigeria. NCBI. Toxics, 4(4), 28. https://doi.org/10.3390/toxics4040028

Karami-Mohajeri, S., \& Abdollahi, M. (2011). Toxic influence of organophosphate, carbamate, and organochlorine pesticides on cellular metabolism of lipids, proteins, and carbohydrates: a systematic review. Hum Exp Toxicol. 30(9), 1119-40. https://doi.org/10.1177/0960327110388959

Kaushik, G., Satya, S., \& Naik, S. N. (2009). Food processing a tool to pesticide residue dissipation-A review. Food Research International Journal. 42, 26-40. https://doi.org/10.1016/j.foodres.2008.09.009 
Kawamura, K., Ishikawa, K., Wada, Y., Kimura, S., Matsumoto, H., Kohro, T., ... Maruyama, Y. (2005). Bilirubin from heme oxygenase-1 attenuates vascular endothelial activation and dysfunction. Arteriosclerosis Thrombosis and Vascular Biology, 25, 155-160. https://doi.org/10.1161/01.ATV.0000148405.18071.6a

Khaled, E., Osama, M. S., Manal, K. M. E., Hussein, H. A., \& Mohamed, R. S. (2017). Microbial, histological and biochemical evidence for the adverse effect of food azo dyes on rats. Journal of Food and Drug Analysis, 1(5), 1-14.

Kim, S. Y., \& Park, S. C. (2012). Physiological Antioxidative Network of the Bilirubin System in Aging and Age-Related Diseases. Front Pharmacology, 3, 45. https://doi.org/10.3389/fphar.2012.00045

Kochmar, J. F., \& Moss, D. W. (1976). Fundamentals of Clinical Chemistry. WB Saunders and Co., Philadelphia, PA., pp: 604.

Kovacic, P. (2003). Mechanism of organophosphates (nerve gases and pesticides) and antidotes: electron transfer and oxidative stress. Current Medical Chemistry, 10, 2705-2709. https://doi.org/10.2174/0929867033456314

Lamirande, E. H., Jiang, A., Zini, H., \& Kodama, C. G. (1997). Rev. Reproduct., 2, 48-54. https://doi.org/10.1530/revreprod/2.1.48

Lewalter, J., \& Korallus, U. (1986). Erythrocyte protein conjugates as a principle of biological $\begin{array}{llllll}\text { monitoring for } & \text { pesticides. } & \text { Toxicol } & \text { Lett., } & 33, & 153 .\end{array}$ https://doi.org/10.1016/0378-4274(86)90079-2

Loeffler, J. E., Potter, J. C., \& Scordelis, S. L. et al. (1976). Long Term exposure of swine to a 14C dichlorvos atmosphere. Journal of Agric Food Chemistry, 24(2), 367-371. https://doi.org/10.1021/jf60204a003

Makni, M., Chtourou, Y., Fetoui, H., Garoui, El M., Boudawara, T., \& Zeghal, N. (2011). Evaluation of the antioxidant, anti-inflammatory and hepatoprotective properties of vanillin in carbon tetrachloride-treated rats. European Journal of Pharmacology, 668(1-2), 133-139. https://doi.org/10.1016/j.ejphar.2011.07.001

Mennear, J. H. (1998). Dichlorvos: A Regulatory Conundrum. Regulatory Toxicology and Pathology Journal, 27, 265-272. https://doi.org/10.1006/rtph.1998.1217

Musa, U., Hati, S. S., Mustapha, A., \& Magaji, G. (2010). Dichlorvos concentrations in locally formulated pesticide (Ota-piapia) utilized in northeastern Nigeria. Scientific Research and Essay Journal, 5(1), 049-054.

Neuzil, J., \& Stocker, R. (1994) Free and albumin-bound bilirubin are efficient co-antioxidants for $\alpha$ - tocopherol, inhibiting plasma and low density lipoprotein lipid peroxidation. Journal of Biological Chemistry, 269, 16712-16719

Obida, M. G., Hati, S. S., Dimari, G. A., \& Ogugbuaja, V. O. (2012). Pesticide residues in bean samples from Northeastern Nigeria. Journal of Food Science Technology, 2, 79-84. 


\section{Macrothink}

Journal of Biology and Life Science

ISSN 2157-6076 2020, Vol. 11, No. 1

Ochei, J., \& Kolhatkar, A. (2008). Medical laboratory Science, Theory and Practices, Tata McGraw-Hill Publishing Co. Ltd, New Delhi, 321-324.

Ojo, A. O., Oyinloye, B. E., Ajiboye, B. O., Ojo, A. B., Akintayo, C. O., \& Okezie, B. (2014). Dichlorvos Induced Nephrotoxicity in Rat Kidney: Protective Effects of Alstonia Boonei Stem Bark Extract. International Journal P., 1, 429-437.

Olabode, O. S., Adeshina, G. O., \& Olapeju, T. R. (2011). A Survey of Agricultural Chemicals Available to Farmers in South Western Nigeria. International Journal of Agricultural Economic and Rural Development, 4(1).

Oyewale, R. O., \& Bamaiyi, L. J. (2013). Management of cowpea insect pests. Sch. Acad J Biosci Sch., 1, 217-226.

Paglia, D. E., \& Valentine, W. N. (1967). Studies on the quantitative and qualitative characterization of erythrocyte glutathione peroxidase. Journal of Laboratory and Clinical Medicine, 70, 158-169.

Poljsak, B., \& Jamik, P. (2010). "Methodology for oxidative state detection in biological systems," in Handbook of Free Radicals: Formation, Types and Effects, D. Kozyrev and V. Slutsky, Eds., Cell Biology Research Progress Series, Nova Science, New York, NY, USA.

Prakasam, A., Sethupathy, S., \& Lalitha, S. (2001). Clinica. Chimica. Acta, 310, 107-112. https://doi.org/10.1016/S0009-8981(01)00487-9

Reitman, S., \& Frankel, S. (1957). Glutamic - pyruvate transaminase assay by colorimetric method. American Journal Clinical Pathology, 28, 56. https://doi.org/10.1093/ajcp/28.1.56

Santos, C. A. F., \& Boiteux, L. S. (2013). Breeding biofortified cowpea lines for semi-arid tropical areas by combining higher seed protein and mineral levels. Journal of Molecular Genetics Research, 12, 6782-6789. https://doi.org/10.4238/2013.December.16.4

Sharma, P., \& Singh, R. (2012). Dichlorvos and lindane induced oxidative stress in rat brain: Protective effects of ginger. Journal of Pharmacognosy Research, (1), 27-32. https://doi.org/10.4103/0974-8490.91031

Sinha, A. (1972). Colorimetric Assay of Catalase. Analytical Biochemistry, 47, 389-394. https://doi.org/10.1016/0003-2697(72)90132-7

Speck-Planche, A., Kleandrova, V. V., \& Scotti, M. T. (2012). Fragment-based approach for the in silico discovery of multi-target insecticides. Chemom Intell Lab System, 111, 39-45. https://doi.org/10.1016/j.chemolab.2011.11.010

Stanton, W. R. (1966). Grain, legumes in Africa, Rome Italy food and Agriculture Organization of the United Nation. p. 183.

Vidyasagar, J., Karunakar, N., Reddy, M. S., Rajnarayana, K., Surender, T., \& Krishna, D. R. (2004). Oxidative stress and antioxidant status in acute organophosphorous insecticide poisoning. Indian Journal of Pharmacology, 36(2), 76-79. 


\section{Macrothink}

Journal of Biology and Life Science ISSN 2157-6076 2020, Vol. 11, No. 1

World Health Organisation (WHO) (1992). International Programme on Chemical Safety, WHO Recommended Classification of Pesticide by Hazard and Guidelines to Classification 1994-1995, UNEP/ILO/WHO.

Wright, A. S., Hutson, D. H., \& Wooder, M. F. (1979). The chemical and biochemical reactivity of dichlorvos. Arch Toxicology Journal. 42(1), 1-18. https://doi.org/10.1007/BF00351820

Yair, S., Ofer, B., Arik, E., Shai, S., Yossi, R., Tzvika, D., \& Amir, K. (2008). Organophosphate Degrading Microorganisms and Enzymes as Biocatalysts in Environmental and Personal Decontamination, Appl. Crit. Rev. Biotechnol, 28, 265-275. https://doi.org/10.1080/07388550802455742

Yang, A., Park, J., Abd El-Aty, A. M., Choi, J. H., Jae-Ho, O., Kisung, K., ... Jung-Ah, D. (2012). Synergistic effect of washing and cooking on the removal of multi-classes of pesticides from various food samples. Food control Journal, 28, 99-105. https://doi.org/10.1016/j.foodcont.2012.04.018

Zhang, W., \& Jiang, F. (2011). Our J. Global Pesticide Consumption and Pollution: With China as a Focus. Proc. Int. Acad. Ecol. Environ. Sci., 1, 125-144.

\section{Copyright Disclaimer}

Copyright for this article is retained by the author(s), with first publication rights granted to the journal.

This is an open-access article distributed under the terms and conditions of the Creative Commons Attribution license (http://creativecommons.org/licenses/by/4.0/). 